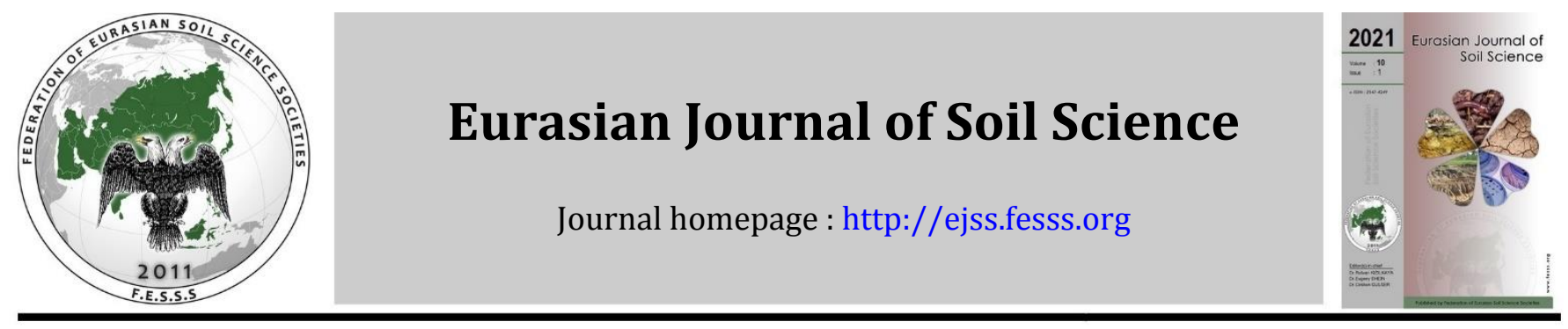

\title{
Evaluation of municipal sewage sludge for Arbuscular mycorrhizal fungi inoculum production
}

\author{
Anju Tanwar a,*, Ajay Singh b, Ashok Aggarwal c, Esha Jangra c, Sergio T. Pichardo d \\ a Department of Botany, Government P.G. College, Ambala Cantt-133001, Haryana, India \\ ${ }^{b}$ Department of Food Technology, Mata Gujri College, Fatehgarh Sahib, Punjab, India \\ c Department of Botany, Kurukshetra University, Kurukshetra-136119, Haryana, India \\ ${ }^{\mathrm{d}}$ Abraham Baldwin Agricultural College (ABAC), School of Agriculture and Natural Resources (SANR) Tifton, GA, USA
}

\section{Article Info}

Received : 01.04.2021

Accepted : 11.07.2021

Available online : 16.07 .2021

\section{Author(s)}

A.Tanwar *

A.Singh

A.Aggarwal

E.Jangra

S.T.Pichardo

* Corresponding author

\section{Abstract}

This experiment was carried out to assess the effect of soil amendment with different concentrations of municipal sewage sludge (SS) as a substrate on inoculum production of two selected arbuscular mycorrhizal fungi (AMF) i.e., Glomus mosseae and Acaulospora laevis. The experiment was a $4 \times 5$ factorial design with four hosts including, maize (Zea mays L.), lemon grass (Cymbopogon nardus (L.) Rendle), palmarosa (Cymbopogon martini (Roxb.) Wats.) and Sesbania (Sesbania aculeata Poir.) and the following five SS concentrations 1) no substrate, 2) $25 \mathrm{~g}$, 3) $50 \mathrm{~g}$, 4) $75 \mathrm{~g}$ and 5) $200 \mathrm{~g} \mathrm{pot}^{-1}$ ) with five replications. After 90 days, the host roots and its rhizosphere soil were examined for fungal mycorrhization in terms of percent of root colonization and AMF spore quantification. Furthermore, we calculated the response of each host in terms of increase in plant height $(\mathrm{cm})$, root length $(\mathrm{cm})$, root, fresh shoots, and dry weight $(\mathrm{g})$. Mycorrhization pattern showed moderate to abundant intraradical mycelium, extraradical mycelium, vesicles, and arbuscules in all the host plants. This pattern varied with a change in the input level of SS. The $75 \mathrm{~g}$ treatment obtained the maximum mycorrhization of both the AMF, while the highest input level was detrimental to AMF and host plants' survival. Among the tested hosts, lemon grass and maize had a tremendous increment in G. mosseae and A. laevis inoculum respectively. Consequently, $75 \mathrm{~g}$ SS with lemon grass is the most compatible hostsubstrate combination capable of maximum G. mosseae and A. laevis spore production and root colonization and so far, highlights the significance of an alternative, cost-effective and affordable carrier medium that can be adopted by farmers as sustainable cultural practices for on farm AMF inoculum production.

Keywords: Acaulospora laevis, Agricultural waste, Glomus mosseae, Sludge utilization strategy, Lemon grass.

(c) 2021 Federation of Eurasian Soil Science Societies. All rights reserved

\section{Introduction}

Among agricultural practices, plant microbe interactions in plant rhizosphere are the interesting environment friendly stimuli that contribute in the development of sustainable agriculture. (Mhlongo et al., 2018). Producing good quality food in a sustainable manner, while mitigating deleterious biotic as well as abiotic stress makes the use of Arbuscular mycorrhizal fungi (AMF) as preferred substitute and achievable production practice (Nzanza et al., 2011). Nevertheless AMF cannot complete their life cycle unless they receive fixed carbon (simple sugars) from their host plant and hence acts as an obligate symbionts (Smith and Read, 2008). AMF mediates trade of important ecological services with their host plants, in particular nutritional benefits together with increased mobilization of nutrients especially immobile $\mathrm{P}$, strengthen water relations, increase plant tolerance against biotic and abiotic stress, soil structure and fertility (Whiteside et al., 2019). Prospects of utilizing native AMF strains in agriculture through diverse eco-friendly

https://doi.org/10.18393/ejss.972157

http://ejss.fesss.org/10.18393/ejss.972157 
avenues such as manipulation of agro-practices, crop rotations and implementation of native AMF inoculum and their practical feasibility has been validated for adoption and recommendation as integrated crop production component (Maiti, 2011). Therefore, considerable effort has focused on finding ways to multiply these fungi for potential applications in agriculture.

Besides their obligate nature, large scale multiplication of AMF in conjunction with appropriate host is more often executed in substrate-based medium (small beds, pots, plots, large fields), substrate less medium (aeroponic) or in vitro conditions like transformed root culture (Kokkoris and Hart, 2019). The soil-based medium is the traditional, economical and highly preferred technique of AMF on large-scale (Kapoor et al., 2008; Selvakumar et al., 2018). Varieties of commercial inoculants are available in the market. However, due to expenses pertaining to maintenance, establishment and multiplication of pure cultures of AMF strains, the cost of carrier substrates, shipping and handling of inoculums has pushed the cost for a farmer even higher. Skill based training program on AMF isolation, establishment and multiplication can be provided by various government agencies to extension workers, agro-dealers and small-holder farmers. Consequently, farmers and nursery owners can conventionally multiply AMF in pots or small plots or nursery beds at their place by utilizing different hosts and substrates, whichever is available.

AMF inoculum encompasses spores, sporocarps, mycelium and colonized root segments (Gupta, 2017; Moreira et al., 2019). A nurse plant with high efficiency of mycorrhization and selection of suitable material for the multiplication and delivery of AMF spores and hyphae is essential. In general, large scale propagation of AMF, multiplication under pot conditions is regarded as the most appropriate system (Feldmann and Grotkass, 2002). Furthermore, this soil can be amended with various other substrate materials to speed up the propagation process (Douds and Schenck, 1990; Gómez-Bellot et al., 2020) like sugarcane bagasse (Tanwar et al., 2013), cattle manure, wood powder and wood (Rodrigues and Rodrigues, 2017), or poultry manure (Uko et al., 2020) to enhance plant growth. Henceforth, various other substrates could be tested for their use in AMF multiplication. The carrier substrate should be easily available one and skillfully selected to allow a stable environment to AMF. Besides it should not be deleterious for AMF, having extended inoculum shelf life, physically and chemically stable, easy to handle and composed of biodegradable and non polluting substances (Mukhongo et al., 2016). Among all, municipal sewage sludge (SS) is a residue from the biological wastewater treatment plants, where domestic waste predominates over industrial one and heavy metal level and pathogens are within acceptable range for agricultural use (Lobo and Filho, 2009).

Disposal of SS is a worldwide problem since it is produced in large volumes due to rapid urbanization. The contemporaneous methods for its disposal encompass dumping in sea, land filling, incineration and agricultural applications as soil fertilizer and soil improver (Pöykiö et al., 2019). Other management practices: include energy and heat recovery, biomass and nutrients $(\mathrm{P})$ recovery and resource usage (Rosiek, 2020). Utilization of SS for agriculture perhaps offer an environmentally acceptable and agronomically favorable means of waste disposal since it is a good source of organic matter and plant nutrient that can have a beneficial effect on plant growth by conditioning soil via improving its biological, chemical and physical properties. Concomitantly, the main limitation of using this resource is its complex composition due to high moisture, ash, toxic heavy metals and organic contaminants which influences the safety of SS (Oladejo et al., 2019).

Soil amendment with SS can impart a sustainable secure practice for the safe disposal of this waste besides improving plant growth, while employing no environmental threats provided there is no heavy metal accumulation in the edible part or in the amended soils (Eid et al., 2020). Several experiments have been conducted on the utilization of SS for crop improvement and most of them have supported and emphasized its use in agriculture (Burducea et al., 2019; Gómez-Bellot et al., 2020). However, excessive application of SS is related to the toxicity of crops due to the aggregation of heavy metals and salt content in the soil (Bettiol and Ghini, 2011). Therefore, it should be used judiciously with an amount able to increase plant growth without showing any phytotoxic symptoms.

Likewise, the growth stage and physiology of the host plant plays an important role in AMF propagation thus, picking up a suitable host as a nurse plant for AMF production is needful (Simpson and Draft, 1990). Therefore, in the present investigation four host plants i.e., Maize (Zea mays L.), Lemon grass (Cymbopogon nardus (L.) Rendle), Palmarosa grass (Cymbopogon martinii (Roxb.) Wats.) and Sesbania/dhaincha (Sesbania aculeata Poir.) were tested for propagation of Glomus mosseae and Acaulospora laevis under different concentrations of SS with the following objectives: a) identify the role of the substrate in enhancing host root colonization and AMF sporulation, b) verify if the addition of AMF to the host plant positively affects its growth c) to identify the most compatible host-substrate combination capable of maximum AMF spore production and root colonization for farm recommendation. 


\section{Material and Methods}

\section{Experimental design}

This experiment was conducted in a greenhouse at Kurukshetra University, Kurukshetra, India. The experiment was a $4 \times 5$ factorial design with two factors A and B in five replications, with 100 pots in total. Factor A was plant species with four plants type $(\mathrm{a} 1=$ maize, $\mathrm{a} 2=$ lemon grass, $\mathrm{a} 3=$ palmarosa grass and $\mathrm{a} 4$ = sesbania), while factor B was five SS concentrations (b1 = no substrate, b2 = $25 \mathrm{~g}, \mathrm{~b} 3=50 \mathrm{~g}, \mathrm{~b} 4=75 \mathrm{~g}$ and $\mathrm{b} 5=200 \mathrm{~g} \mathrm{pot}^{-1}$ ).

\section{Soil characteristics}

The soil characteristics were: sand $=64.2 \%$, silt $=21.81 \%$, clay $=3.90 \%, \mathrm{pH}=6.8 \pm 0, \mathrm{EC}=0.25 \mathrm{dS} \cdot \mathrm{m}^{-1}$, organic carbon $=0.40 \%$, total $\mathrm{N}=0.042 \%, \mathrm{P}=0.000247 \mathrm{~kg} \cdot \mathrm{m}^{-2}, \mathrm{~K}=0.217 \mathrm{~kg} \cdot \mathrm{m}^{-2}$ and $\mathrm{S}=0.01480 \mathrm{mg} \cdot \mathrm{g}^{-1}$.

\section{Preparation of initial AMF inoculum}

The rhizosphere soil of vegetable crops were examined for the isolation of healthy AMF spores using the technique of wet sieving and decanting protocol (Gerdemann and Nicolson, 1963) and later the manual of Schenck and Perez (1990) was used for their identification. AMF strains (Glomus mosseae and Acaulospora laevis) were found to dominate in the samples and hence selected. Identified spores were initially cultivated for a period of 60 days in association with the Maize plant by using the funnel technique (Menge and Timmer, 1982) with sterilized soil: sand (3:1) mixture. Ahead, plant roots were analyzed for mycorrhizal colonization by the protocol of Phillips and Hayman (1970) and rhizosphere soil was analysed for the number of AM spores. This starter inoculum of respective AMF fungi was then employed for their mass multiplication with different hosts and SS concentrations under pot conditions.

\section{Selection and preparation of substrate}

SS cakes were obtained from Sewage Treatment Plant, Yamunanagar. It was grounded to fine powder and analyzed as listed in Table 1.

Table 1. Physical and chemical characteristics of sewage sludge

\begin{tabular}{|c|c|c|c|}
\hline 1. & $\mathrm{pH}$ & 5.57 & $\pm \quad 0.11$ \\
\hline 2. & $\mathrm{EC}\left(\mathrm{dS} \mathrm{m} \mathrm{m}^{-1}\right)$ & 5.87 & 0.04 \\
\hline 3. & Chlorides $\left(\mathrm{mg} \mathrm{g}^{-1}\right)$ & 1.33 & 0.15 \\
\hline 4. & Hardness $\left(\mathrm{mg} \mathrm{g}^{-1}\right)$ & 9.50 & 0.20 \\
\hline 5. & Alkalinity (mg g ${ }^{-1}$ ) & 27.00 & 0.50 \\
\hline 6. & Ortho phosphate $\left(\mathrm{mg} \mathrm{g}^{-1}\right)$ & 1.81 & \pm \\
\hline 8. & Nitrate $\left(\mathrm{mg} \mathrm{g}^{-1}\right)$ & 0.24 & \pm \\
\hline
\end{tabular}

\section{Selection of the host plant}

Four different host plants (Maize, Lemon grass, Palmarosa grass and Sesbania) were tested for each AMF strain. All these plants are monocots and members of Poaceae (Maize, Lemon grass, Palmarosa grass) except for Sesbania that is a Leguminosae.

\section{Experimental setup}

The top layer of soil up to $3 \mathrm{~cm}$ was collected from a botanical garden. It was then dried under the sun, grinded to remove lumps of soil, strained through a sieve $(2 \mathrm{~mm})$. Soil was mixed with sand in the ratio of $3: 1(\mathrm{w} / \mathrm{w})$. Prior to use, it was sterilized in an autoclave $\left(121^{\circ} \mathrm{C}, 30 \mathrm{~min}\right)$ for two consecutive days. Earthen pots $(25.4 \times 25 \mathrm{~cm})$ were filled with four different concentrations of SS (no substrate, $25 \mathrm{~g}, 50 \mathrm{~g}, 75 \mathrm{~g}$ and, $200 \mathrm{~g} \mathrm{pot}^{-1}$ ) and sand: soil, to make a total volume of $2 \mathrm{~kg}$. The control pots did not receive SS. It was followed by the addition of $200 \mathrm{~g}$ of respective AMF initial inoculum (Glomus mosseae and Acaulospora laevis) that consist of chopped colonized Maize root segments and its rhizosphere soil (350-420 spores 100 $\mathrm{g}^{-1}$.

Healthy seeds of Maize and Sesbania, were disinfected (0.5 \% sodium hypochlorite for $10 \mathrm{~min}$ ), and then rinsed with sterilized deionized water. Five to ten seeds were sowed above the added inoculum. After 15 days, Maize and Sesbania plants were lessened to three plants per pot. Likewise, Lemon and Palmarosa grasses were acquired from Chaudhary Devi Lal Herbal Garden, Chuharpur, Yamunanagar (Haryana), India. The overhead foliage part of each grass was pruned to the height of $15 \mathrm{~cm}$ and, roots were disinfected with sodium hypochlorite $(0.5 \%)$. In each pot, one stiff upright tiller with rhizomatous rootstock was planted. Pots were watered daily along with the addition of Hoagland's solution @ $100 \mathrm{ml} \mathrm{pot}^{-1}$ (Hoagland and Arnon, 1950) (except $\mathrm{KH}_{2} \mathrm{PO}_{4}$ ) after every 15 days interval. 


\section{Plant harvest and its analysis}

After 90 days of growth, vegetative growth response was determined. Increase in plant height (cm), root length $(\mathrm{cm})$, roots, and shoots fresh weight $(\mathrm{g})$ was determined first. Shoot and roots were dried with a hot air oven at $70^{\circ} \mathrm{C}$ to get a constant dry weight of shoot and root (g). The percentage of AMF root colonization and AMF spores were quantified using the previously discussed methods.

\section{Statistical analysis}

The experimental data were analyzed with an analysis of variance, and means were separated with the least significant difference (LSD) test using the Statistical Package for Social Sciences (SPSS) (ver. 11.5, Chicago (IL), USA).

\section{Results}

As per the data presented in Tables 2 and 3 for analysis of variance, the various values for host types, sewage sludge concentration as well as their interaction on inoculum production of G. mosseae and A. laevis and plant growth were found significant $(\mathrm{P}<0.05)$.

Table 2. Analysis of variance for effect of host plant, substrate concentration and their interaction on inoculum production of $G$. mosseae.

\begin{tabular}{|c|c|c|c|c|c|c|c|c|c|}
\hline \multirow[t]{2}{*}{ Source } & \multirow[t]{2}{*}{ DF } & \multirow[t]{2}{*}{$\begin{array}{r}\text { AMF spore } \\
\text { number }\end{array}$} & \multirow{2}{*}{$\begin{array}{r}\text { AMF root } \\
\text { colonization } \\
(\%)\end{array}$} & \multirow{2}{*}{$\begin{array}{r}\text { Plant } \\
\text { height } \\
\text { (cm) }\end{array}$} & \multicolumn{2}{|c|}{$\begin{array}{l}\text { Above ground } \\
\text { weight }(\mathrm{g})\end{array}$} & \multirow{2}{*}{$\begin{array}{r}\text { Root } \\
\text { length } \\
\text { (cm) }\end{array}$} & \multicolumn{2}{|c|}{ Root weight (g) } \\
\hline & & & & & Fresh & Dry & & Fresh & Dry \\
\hline $\mathrm{H}$ & 3 & & $65.765^{* *}$ & $240.977^{* *}$ & 534.782 & 143. & $31.879^{* *}$ & 545.55 & $185.725^{* *}$ \\
\hline $\mathrm{S}$ & 4 & 517. & $554.520^{* *}$ & $95.290^{* *}$ & $188.405^{* *}$ & 59.1 & $268.770^{* *}$ & $118.122^{* *}$ & $59.817^{* *}$ \\
\hline $\mathrm{H} \times \mathrm{S}$ & 12 & $71.855^{* *}$ & $90.023^{* *}$ & $17.586^{* *}$ & $31.973^{* *}$ & $32.516^{* *}$ & $24.127^{* *}$ & $30.430^{* *}$ & $28.654^{* *}$ \\
\hline
\end{tabular}

H: host type, S: substrate concentration, ${ }^{* *}=$ significant at $P<0.05$ for various values, $\mathrm{DF}=$ degree of freedom

Table 3. Analysis of variance for effect of host plant, substrate concentration and their interaction on inoculum production of $A$. laevis.

\begin{tabular}{|c|c|c|c|c|c|c|c|c|c|}
\hline \multirow[t]{2}{*}{ Source } & \multirow[t]{2}{*}{ DF } & \multirow[t]{2}{*}{$\begin{array}{l}\text { AMF spore } \\
\text { number }\end{array}$} & \multirow{2}{*}{$\begin{array}{r}\text { AMF root } \\
\text { colonization } \\
(\%)\end{array}$} & \multirow{2}{*}{$\begin{array}{r}\text { Plant } \\
\text { height } \\
(\mathrm{cm}) \\
\end{array}$} & \multicolumn{2}{|c|}{$\begin{array}{l}\text { Above ground } \\
\text { weight }(\mathrm{g})\end{array}$} & \multirow{2}{*}{$\begin{array}{r}\text { Root } \\
\text { length } \\
(\mathrm{cm}) \\
\end{array}$} & \multicolumn{2}{|c|}{ Root weight (g) } \\
\hline & & & & & Fresh & Dry & & Fresh & Dry \\
\hline $\mathrm{H}$ & 3 & & $61.009^{* *}$ & $96.360^{* *}$ & 347 & & $856.422^{* *}$ & 73. & $25.283^{* *}$ \\
\hline S & & & 338 & 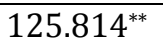 & 132.92 & & 19 & 41 & $42.257^{* *}$ \\
\hline $\mathrm{H} \times \mathrm{S}$ & 12 & $32.072^{* *}$ & $33.835^{* *}$ & $45.045^{* *}$ & $59.323^{* *}$ & $18.069^{* *}$ & $42.235^{* *}$ & $22.914^{* *}$ & $35.992^{* *}$ \\
\hline
\end{tabular}

$\mathrm{H}$ : host type, S: substrate concentration, ${ }^{* *}=$ significant at $P<0.05$ for various values, $\mathrm{DF}=$ degree of freedom

\section{Mycorrhization pattern of $G$. mosseae}

In all the selected host plants, mycorrhization in terms of percent mycorrhizal root colonization and number of AMF spores were recorded. Moderate to abundant intraradical, extraradical mycelium, vesicles and arbuscules were detected that vary with change in the input level of SS.

Great variation was noticed in $G$. mosseae spore number and root colonization level that ranges from 22.22 to 290.6 (AMF spore number) and 16.44 to $100 \%$ (AMF colonization) with the lowest numerical values recorded in control plants without any substrate (Table 4). An increase in the input level of SS caused a steady increase in mycorrhization in all the plants up to $75 \mathrm{~g}$ addition level only and, any further increase, decreased the mycorrhization. Among all the hosts tested, the effect of SS (75 g) was significant and in the presence of Lemon grass had the greatest AMF spore number and colonized roots which also showed abundant vesicles. The second greatest increment in AMF spores (222.2 \pm 16.3$)$ and level of colonization (95.32 \pm 4.48$)$ was obtained in Maize with $75 \mathrm{~g}$, followed by Sesbania with $50 \mathrm{~g}$ and Palmarosa grass with $75 \mathrm{~g}$ respectively, and sporulation and root colonization were correlated.

\section{Plant growth characteristics with $G$. mosseae}

A perusal of the data presented in Table 5 showed that an increase in the colonization level of plant roots increased plant height, shoot fresh and dry weight, root length, root fresh and, dry weight. It was noticed that an increase in the addition level of SS in the potting mixture showed positive results in terms of increasing mycorrhization and plant growth as well. However, a maximum addition level of $200 \mathrm{~g}$ was inhibitory to all the plants except for Lemon grass, where $200 \mathrm{~g} \mathrm{SS}$ amended plants exhibited the highest plant growth unlike to the highest mycorrhization shown by $75 \mathrm{~g}$ supplemented plants. However, the values recorded with $200 \mathrm{~g}$ were higher as compared to unamended control. 
Table 4. Efficacy of sewage sludge on mycorrhization pattern of G. mosseae with different hosts.

\begin{tabular}{|c|c|c|c|c|c|c|}
\hline \multirow[t]{2}{*}{ Host type } & \multirow{2}{*}{$\begin{array}{l}\text { Substrate } \\
\text { concentration } \\
\left(\mathrm{g} \mathrm{pot}^{-1}\right)\end{array}$} & \multirow{2}{*}{$\begin{array}{l}\text { AMF spore } \\
\text { number }\end{array}$} & \multirow{2}{*}{$\begin{array}{l}\text { AMF root } \\
\text { colonization } \\
(\%)\end{array}$} & \multicolumn{3}{|c|}{ Pattern of colonization } \\
\hline & & & & Mycelium & Vesicles & Arbuscules \\
\hline \multirow[t]{5}{*}{ Maize } & 0 & $35.65 \pm 3.76 j$ & $21.11 \pm 4.87 f$ & + & - & - \\
\hline & 25 & $144.2 \pm 12.64 \mathrm{~g} \dagger$ & $56.57 \pm 7.05 c$ & + & + & - \\
\hline & 50 & $181.6 \pm 12.14 \mathrm{f}$ & $68.50 \pm 5.48 b$ & + & + & + \\
\hline & 75 & $222.2 \pm 16.30 \mathrm{c}$ & $95.32 \pm 4.48 \mathrm{a}$ & ++ & + & ++ \\
\hline & 200 & $193.8 \pm 17.94 d$ & $44.50 \pm 5.70 \mathrm{~d}$ & + & - & + \\
\hline \multirow[t]{5}{*}{ Lemon grass } & 0 & $36.22 \pm 1.87 j$ & $26.87 \pm 4.11 \mathrm{f}$ & + & + & - \\
\hline & 25 & $101.4 \pm 15.14 \mathrm{~g}$ & $55.71 \pm 8.21 c$ & + & + & + \\
\hline & 50 & $126.6 \pm 19.30 \mathrm{~g}$ & $74.50 \pm 5.70 \mathrm{~d}$ & + & ++ & + \\
\hline & 75 & $290.6 \pm 19.24 a$ & $100.0 \pm 0$ & +++ & + & ++ \\
\hline & 200 & $181.2 \pm 16.41 \mathrm{f}$ & $88.50 \pm 5.48 b$ & +++ & +++ & +++ \\
\hline \multirow{5}{*}{ Palmarosa grass } & 0 & $22.22 \pm 7.43 \mathrm{j}$ & $16.44 \pm 3.21 \mathrm{f}$ & + & - & - \\
\hline & 25 & $78.20 \pm 11.88 \mathrm{i}$ & $28.20 \pm 3.82 \mathrm{e}$ & + & + & + \\
\hline & 50 & $124.4 \pm 24.15 \mathrm{fg}$ & $54.32 \pm 8.76 c$ & + & + & + \\
\hline & 75 & $160.2 \pm 18.61 \mathrm{~cd}$ & $86.16 \pm 5.64 a$ & +++ & + & ++ \\
\hline & 200 & $130.6 \pm 15.45 \mathrm{fg}$ & $46.92 \pm 4.13 \mathrm{~d}$ & + & - & + \\
\hline \multirow[t]{5}{*}{ Sesbania } & 0 & $50.56 \pm 6.23 \mathrm{j}$ & $33.35 \pm 5.05 f$ & + & - & - \\
\hline & 25 & $128.2 \pm 19.34 \mathrm{fg}$ & $53.62 \pm 8.24 c$ & + & + & + \\
\hline & 50 & $202.6 \pm 19.82 b$ & $94.82 \pm 5.23 \mathrm{ab}$ & +++ & + & ++ \\
\hline & 75 & $197.2 \pm 14.41 \mathrm{e}$ & $45.40 \pm 4.56 \mathrm{~d}$ & + & - & - \\
\hline & 200 & $89.60 \pm 13.05 \mathrm{~h}$ & $27.26 \pm 4.25 \mathrm{e}$ & + & - & - \\
\hline
\end{tabular}

Each value is a mean of five replicates, \pm : standard deviation, AMF: Arbuscular mycorrhizal Fungi, -: absent, +: scanty, ++ : moderate, +++ : abundant

tindicates the level of significance at $P \leq 0.05$ level. Means followed by same letter/s within a column are not significantly different over one another (Least significant difference test, $P \leq 0.05$ ).

Table 5: Efficacy of sewage sludge and G. mosseae on growth response of Maize, Lemon grass, Palmarosa grass and Sesbania.

\begin{tabular}{|c|c|c|c|c|c|c|c|}
\hline \multirow[t]{2}{*}{ Host type } & \multirow{2}{*}{$\begin{array}{l}\text { Substrate } \\
\text { concentration } \\
\left(\mathrm{g} \mathrm{pot}^{-1}\right)\end{array}$} & \multirow{2}{*}{$\begin{array}{l}\text { Plant height } \\
(\mathrm{cm})\end{array}$} & \multicolumn{2}{|c|}{ Above ground weight (g) } & \multirow{2}{*}{$\begin{array}{l}\text { Root length } \\
(\mathrm{cm})\end{array}$} & \multicolumn{2}{|c|}{ Root weight (g) } \\
\hline & & & Fresh & Dry & & Fresh & Dry \\
\hline \multirow[t]{5}{*}{ Maize } & 0 & $21.28 \pm 2.29 \dagger$ & $3.53 \pm 0.48$ & $1.13 \pm 0.12$ & $10.05 \pm 0.87$ & $1.71 \pm 0.16$ & $1.16 \pm 0.11$ \\
\hline & 25 & $30.48 \pm 2.77$ & $4.17 \pm 0.19$ & $1.43 \pm 0.20$ & $18.16 \pm 1.57$ & $2.23 \pm 0.17$ & $1.27 \pm 0.13$ \\
\hline & 50 & $39.40 \pm 3.08$ & $7.69 \pm 0.59$ & $3.05 \pm 0.27$ & $26.00 \pm 1.78$ & $3.85 \pm 0.20$ & $2.18 \pm 0.12$ \\
\hline & 75 & $41.36 \pm 2.14$ & $10.4 \pm 0.85$ & $3.64 \pm 0.52$ & $31.66 \pm 2.46$ & $4.99 \pm 0.24$ & $2.87 \pm 0.21$ \\
\hline & 200 & $33.13 \pm 2.03$ & $5.50 \pm 0.58$ & $2.16 \pm 0.17$ & $21.90 \pm 1.72$ & $3.23 \pm 0.16$ & $1.85 \pm 0.35$ \\
\hline \multirow[t]{5}{*}{ Lemon grass } & 0 & $50.48 \pm 4.24$ & $10.2 \pm 0.79$ & $3.56 \pm 0.19$ & $10.22 \pm 1.63$ & $6.27 \pm 0.86$ & $2.21 \pm 0.30$ \\
\hline & 25 & $63.94 \pm 10.8$ & $19.3 \pm 2.24$ & $5.03 \pm 0.47$ & $14.20 \pm 1.58$ & $7.73 \pm 0.55$ & $3.34 \pm 0.35$ \\
\hline & 50 & $76.60 \pm 8.11$ & $25.9 \pm 1.71$ & $5.19 \pm 0.34$ & $22.20 \pm 2.18$ & $9.17 \pm 0.76$ & $3.91 \pm 0.17$ \\
\hline & 75 & $77.34 \pm 11.6$ & $28.5 \pm 2.73$ & $5.05 \pm 0.42$ & $26.14 \pm 1.52$ & $8.70 \pm 0.78$ & $3.45 \pm 0.39$ \\
\hline & 200 & $88.70 \pm 7.10$ & $32.7 \pm 2.72$ & $6.97 \pm 0.26$ & $30.22 \pm 1.55$ & $12.3 \pm 1.58$ & $4.79 \pm 0.42$ \\
\hline Palmarosa & 0 & $20.54 \pm 2.99$ & $6.86 \pm 0.50$ & $2.17 \pm 0.30$ & $12.62 \pm 2.20$ & $1.22 \pm 0.16$ & $0.86 \pm 0.13$ \\
\hline \multirow[t]{4}{*}{ grass } & 25 & $38.42 \pm 2.47$ & $10.3 \pm 1.16$ & $4.24 \pm 0.49$ & $17.82 \pm 2.10$ & $2.85 \pm 0.35$ & $1.14 \pm 0.10$ \\
\hline & 50 & $50.52 \pm 3.20$ & $16.8 \pm 1.70$ & $5.06 \pm 0.65$ & $14.88 \pm 1.90$ & $4.33 \pm 0.21$ & $2.25 \pm 0.15$ \\
\hline & 75 & $56.48 \pm 2.86$ & $23.1 \pm 2.22$ & $6.92 \pm 0.55$ & $25.22 \pm 3.23$ & $6.69 \pm 0.56$ & $3.04 \pm 0.33$ \\
\hline & 200 & $43.14 \pm 2.81$ & $15.5 \pm 1.89$ & $4.10 \pm 0.48$ & $20.20 \pm 2.57$ & $3.03 \pm 0.51$ & $1.27 \pm 0.22$ \\
\hline \multirow[t]{5}{*}{ Sesbania } & 0 & $60.34 \pm 5.91$ & $7.71 \pm 0.87$ & $3.34 \pm 0.79$ & $13.54 \pm 1.57$ & $3.06 \pm 0.44$ & $2.07 \pm 0.22$ \\
\hline & 25 & $80.40 \pm 5.10$ & $12.2 \pm 1.25$ & $5.57 \pm 0.83$ & $25.98 \pm 2.43$ & $3.58 \pm 0.20$ & $2.32 \pm 0.31$ \\
\hline & 50 & $90.42 \pm 5.15$ & $15.5 \pm 1.59$ & $7.45 \pm 1.05$ & $32.90 \pm 3.11$ & $5.90 \pm 0.18$ & $2.95 \pm 0.23$ \\
\hline & 75 & $68.56 \pm 3.70$ & $11.5 \pm 1.58$ & $5.60 \pm 0.71$ & $25.55 \pm 3.67$ & $3.96 \pm 0.47$ & $2.50 \pm 0.63$ \\
\hline & 200 & $52.78 \pm 4.85$ & $6.57 \pm 1.53$ & $3.15 \pm 0.48$ & $14.74 \pm 1.97$ & $2.78 \pm 0.53$ & $1.44 \pm 0.23$ \\
\hline
\end{tabular}

Each value is a mean of five replicates, \pm : standard deviation

tindicates the level of significance at $P \leq 0.05$ level. Means followed by same letter/s within a column are not significantly different over one another (Least significant difference test, $P \leq 0.05$ ). 


\section{Mycorrhization pattern of $A$. laevis}

While for the multiplication of $A$. laevis, a similar trend was depicted regarding the influence of substrate addition on mycorrhization (Table 6). According to the results in Table 6, the $75 \mathrm{~g}$ SS amendment obtained a significant AMF multiplication. A further inoculum addition had an inhibitory effect on the AMF. Meanwhile, $100 \%$ colonized roots and maximum spores were obtained with $75 \mathrm{~g}$ SS on Maize, followed by Lemon grass, Sesbania, and Palmarosa. Results also revealed the presence of an extensive and abundant mycelium colonizing Maize, Lemon grass, and Sesbania roots, while abundant vesicles and arbuscules were formed in Maize and Sesbania roots only. Vesicle and arbuscule formation were not detected in some of the treatments having an excess of SS after 90 days of the experiment.

Table 6: Efficacy of sewage sludge on mycorrhization pattern of A. laevis.

\begin{tabular}{|c|c|c|c|c|c|c|}
\hline \multirow[t]{2}{*}{ Host type } & \multirow{2}{*}{$\begin{array}{l}\text { Substrate } \\
\text { concentration } \\
\left(\mathrm{g} \mathrm{pot}^{-1}\right) \\
\end{array}$} & \multirow{2}{*}{$\begin{array}{l}\text { AMF spore } \\
\text { number }\end{array}$} & \multirow{2}{*}{$\begin{array}{l}\text { AMF root } \\
\text { colonization } \\
(\%)\end{array}$} & \multicolumn{3}{|c|}{ Pattern of colonization } \\
\hline & & & & Myce & & \\
\hline \multirow[t]{5}{*}{ Maize } & 0 & $38.55 \pm 4.07 \mathrm{k}$ & $25.87 \pm 3.02 \mathrm{~h}$ & + & + & + \\
\hline & 25 & $173.6 \pm 14.11 \mathrm{~d} \dagger$ & $44.50 \pm 5.70 \mathrm{e}$ & + & + & + \\
\hline & 50 & $164.0 \pm 37.14 \mathrm{f}$ & $55.96 \pm 9.81 d$ & + & ++ & + \\
\hline & 75 & $221.8 \pm 15.71 \mathrm{a}$ & $100.0 \pm 0 \mathrm{a}$ & +++ & +++ & +++ \\
\hline & 200 & $80.60 \pm 10.38 \mathrm{i}$ & $32.86 \pm 4.86 \mathrm{fg}$ & + & + & - \\
\hline \multirow[t]{5}{*}{ Lemon grass } & 0 & $20.87 \pm 3.02 \mathrm{k}$ & $16.40 \pm 2.77 \mathrm{~h}$ & + & - & - \\
\hline & 25 & $130.0 \pm 15.93 \mathrm{gh}$ & $54.35 \pm 4.32 \mathrm{~d}$ & + & + & + \\
\hline & 50 & $179.0 \pm 19.49 \mathrm{~cd}$ & $78.82 \pm 7.96 b$ & ++ & + & + \\
\hline & 75 & $208.6 \pm 15.61 \mathrm{ab}$ & $84.00 \pm 8.94 c$ & ++ & ++ & + \\
\hline & 200 & $65.00 \pm 10.91$ & $36.26 \pm 7.36 \mathrm{f}$ & + & - & + \\
\hline \multirow[t]{5}{*}{ Palmarosa grass } & 0 & $23.33 \pm 2.66 \mathrm{k}$ & $10.34 \pm 2.11 \mathrm{~h}$ & + & - & - \\
\hline & 25 & $57.20 \pm 8.22 \mathrm{j}$ & $26.16 \pm 5.44 \mathrm{~g}$ & + & + & - \\
\hline & 50 & $112.8 \pm 15.05 \mathrm{~h}$ & $57.97 \pm 5.61 \mathrm{~d}$ & + & + & + \\
\hline & 75 & $181.4 \pm 13.22 \mathrm{c}$ & $71.00 \pm 4.18 c$ & ++ & ++ & + \\
\hline & 200 & $169.0 \pm 10.58 \mathrm{e}$ & $76.16 \pm 8.68 \mathrm{bc}$ & ++ & + & ++ \\
\hline \multirow[t]{5}{*}{ Sesbania } & 0 & $67.87 \pm 2.55 \mathrm{k}$ & $33.67 \pm 3.45 h$ & + & + & + \\
\hline & 25 & $150.4 \pm 11.97 \mathrm{~g}$ & $46.79 \pm 7.28 \mathrm{e}$ & + & + & + \\
\hline & 50 & $174.2 \pm 10.96 \mathrm{~d}$ & $86.45 \pm 8.19 b$ & ++ & + & ++ \\
\hline & 75 & $204.2 \pm 16.16 a b$ & $87.32 \pm 3.67 \mathrm{ab}$ & ++ & + & ++ \\
\hline & 200 & $167.4 \pm 11.65 \mathrm{ef}$ & $78.50 \pm 5.48 c$ & ++ & +++ & +++ \\
\hline
\end{tabular}

Each value is a mean of five replicates, \pm : standard deviation, AMF: Arbuscular mycorrhizal Fungi, -: absent, +: scanty, ++ : moderate, +++ : abundant

†indicates the level of significance at $P \leq 0.05$ level. Means followed by same letter/s within a column are not significantly different over one another (Least significant difference test, $P \leq 0.05$ ).

\section{Plant growth characteristics with $A$. laevis}

Likewise, with $A$. laevis, the results for plant growth characteristics were also in line with mycorrhization level (Table 7). Treatments showing highest mycorrhization also showed the highest plant growth parameters except for Palmarosa grass, in which instead of maximum mycorrhization shown by plants under 75 g SS addition, a maximum addition level of SS (200 g) showed the highest plant growth characteristics.

Overall, the results showed maximum benefits with $75 \mathrm{~g}$ of SS addition in Lemon grass for G. mosseae inoculum production while for $A$. laevis, Maize, and Lemon grass with $75 \mathrm{~g}$ SS promoted maximum increment in A. laevis propagules with the highest percent of colonization rate. Moreover, other hosts also exhibited a tremendous increase in inoculum intensity with different concentrations of substrate.

\section{Discussion}

Production of AMF inocula is as complex in development as tedious to propagate owing to the involvement of biotechnological expertise. In addition to it, consideration of related legal, ethical, educational and commercial requirements are also in line while working on it (Gianinnazi and Vosátka, 2004). In this investigation all the host plants were highly selective for the AMF multiplication. The tested host plants were either members of Poaceae or Leguminosae and formed effective AMF symbiosis which is ascribed to the high density of secondary roots supporting colonization of root and spore propagation as well (Bhowmik et 
al., 2015). Among all the tested host plants Lemon grass had the highest inoculum production level of $G$. mosseae. In comparison, Maize manifests maximum compatibility with A. laevis followed by Lemon grass. Vesicles and arbuscules were abundantly formed in all these plant roots showing the formation of efficient symbiosis between both the partners. Host mycorrhizal dependency is genetically fixed, and the level of mycorrhizal dependency can be expressed up to the extent of an individual, or as a gradient within an ecological niche and relevant environment context of the host (Feldmann et al., 2008). The suitability of some host plant species to stimulate AMF propagation could be due to the secretion of a wide variety of water-soluble and volatile organic compounds, endogenous hormone level characteristics helping as a stimulant, attractants, nutrient sources and even as genetic regulatory signals for AMF colonization (Koide and Schreiner, 1992). Research by Ryan and Graham (2002) and Liu and Wang (2003) support that a variation in root type, its anatomy and morphology, carbon biomass, and environmental interactions also influence AMF symbiosis.

Table 7: Efficacy of sewage sludge and A. laevis on growth response of Maize, Lemon grass, Palmarosa grass and Sesbania.

\begin{tabular}{|c|c|c|c|c|c|c|c|}
\hline \multirow[t]{2}{*}{ Host type } & \multirow{2}{*}{$\begin{array}{l}\text { Substrate } \\
\text { concentration } \\
\left(\mathrm{g} \mathrm{pot}^{-1}\right)\end{array}$} & \multirow{2}{*}{$\begin{array}{l}\text { Plant height } \\
\text { (cm) }\end{array}$} & \multicolumn{2}{|c|}{ Above ground weight (g) } & \multirow{2}{*}{$\begin{array}{l}\text { Root length } \\
(\mathrm{cm})\end{array}$} & \multicolumn{2}{|c|}{ Root weight (g) } \\
\hline & & & Fresh & Dry & & Fresh & Dry \\
\hline \multirow[t]{5}{*}{ Maize } & 0 & $29.48 \pm 6.31 \dagger$ & $2.54 \pm 0.51$ & $0.95 \pm 0.14$ & $12.7 \pm 1.89$ & $2.15 \pm 0.23$ & $0.85 \pm 0.21$ \\
\hline & 25 & $35.86 \pm 3.12$ & $5.63 \pm 0.70$ & $2.41 \pm 0.54$ & $16.6 \pm 1.87$ & $2.87 \pm 0.46$ & $1.25 \pm 0.31$ \\
\hline & 50 & $40.78 \pm 3.81$ & $8.34 \pm 0.77$ & $3.49 \pm 0.41$ & $21.0 \pm 2.54$ & $4.69 \pm 0.91$ & $1.92 \pm 0.24$ \\
\hline & 75 & $44.08 \pm 3.86$ & $9.62 \pm 0.92$ & $3.56 \pm 0.39$ & $26.7 \pm 3.10$ & $5.36 \pm 0.61$ & $2.22 \pm 0.22$ \\
\hline & 200 & $30.40 \pm 3.67$ & $2.93 \pm 0.56$ & $1.22 \pm 0.22$ & $18.4 \pm 1.60$ & $3.04 \pm 0.91$ & $1.14 \pm 0.15$ \\
\hline \multirow[t]{5}{*}{ Lemon grass } & 0 & $42.22 \pm 6.03$ & $8.38 \pm 0.73$ & $2.65 \pm 0.44$ & $6.44 \pm 1.13$ & $3.77 \pm 0.42$ & $1.18 \pm 0.16$ \\
\hline & 25 & $54.72 \pm 5.08$ & $23.6 \pm 3.94$ & $3.59 \pm 0.46$ & $12.7 \pm 1.51$ & $5.28 \pm 0.45$ & $2.44 \pm 0.46$ \\
\hline & 50 & $57.66 \pm 4.54$ & $12.7 \pm 0.81$ & $4.25 \pm 0.70$ & $17.4 \pm 1.28$ & $7.53 \pm 1.03$ & $3.54 \pm 0.45$ \\
\hline & 75 & $65.98 \pm 4.24$ & $23.0 \pm 2.17$ & $5.28 \pm 0.64$ & $10.8 \pm 1.00$ & $5.54 \pm 0.60$ & $2.64 \pm 0.48$ \\
\hline & 200 & $34.52 \pm 2.88$ & $8.07 \pm 0.78$ & $2.65 \pm 0.70$ & $5.68 \pm 0.84$ & $3.43 \pm 0.43$ & $0.94 \pm 0.16$ \\
\hline \multirow[t]{5}{*}{ Palmarosa grass } & 0 & $17.48 \pm 1.63$ & $7.44 \pm 0.34$ & $2.56 \pm 0.49$ & $36.8 \pm 2.87$ & $2.98 \pm 0.22$ & $0.87 \pm 0.17$ \\
\hline & 25 & $28.64 \pm 2.65$ & $12.4 \pm 1.05$ & $4.38 \pm 0.41$ & $48.1 \pm 2.96$ & $3.71 \pm 0.51$ & $1.44 \pm 0.29$ \\
\hline & 50 & $36.32 \pm 2.50$ & $11.4 \pm 2.00$ & $4.86 \pm 0.36$ & $45.7 \pm 2.96$ & $4.35 \pm 0.52$ & $1.37 \pm 0.43$ \\
\hline & 75 & $48.88 \pm 2.02$ & $17.4 \pm 1.70$ & $5.65 \pm 0.38$ & $55.1 \pm 3.07$ & $5.11 \pm 0.63$ & $2.49 \pm 0.39$ \\
\hline & 200 & $56.26 \pm 2.42$ & $22.8 \pm 1.02$ & $5.99 \pm 0.28$ & $62.9 \pm 3.19$ & $5.59 \pm 0.58$ & $2.89 \pm 0.39$ \\
\hline \multirow[t]{5}{*}{ Sesbania } & 0 & $22.40 \pm 2.83$ & $2.75 \pm 0.33$ & $0.97 \pm 0.22$ & $4.68 \pm 0.89$ & $2.30 \pm 0.42$ & $0.99 \pm 0.23$ \\
\hline & 25 & $25.12 \pm 1.99$ & $2.28 \pm 0.23$ & $1.15 \pm 0.19$ & $7.12 \pm 0.91$ & $1.98 \pm 0.31$ & $1.18 \pm 0.20$ \\
\hline & 50 & $21.86 \pm 2.70$ & $3.89 \pm 0.22$ & $1.42 \pm 0.34$ & $8.06 \pm 1.09$ & $2.54 \pm 0.36$ & $1.03 \pm 0.21$ \\
\hline & 75 & $27.74 \pm 2.38$ & $4.52 \pm 0.41$ & $1.73 \pm 0.21$ & $10.1 \pm 1.23$ & $3.06 \pm 0.24$ & $1.27 \pm 0.25$ \\
\hline & 200 & $36.40 \pm 2.40$ & $4.99 \pm 0.40$ & $2.20 \pm 0.43$ & $13.4 \pm 1.58$ & $4.00 \pm 0.41$ & $1.63 \pm 0.25$ \\
\hline
\end{tabular}

Each value is a mean of five replicates, \pm : standard deviation

tindicates the level of significance at $P \leq 0.05$ level. Means followed by same letter/s within a column are not significantly different over one another (Least significant difference test, $P \leq 0.05$ ).

Excessive A. laevis multiplication in association with Maize roots corroborate to the extensive and fastgrowing root system of Maize, able to tolerate and adapt to the changing environmental conditions due to the addition of substrate (Mukerji et al., 2002). This result confirms the findings of Tahat et al. (2012), who also observed maximum spore number and colonized roots with Maize compared to Sorghum, Barley and Lentil. However, the results of this research are in contradiction with the findings of some other researchers including Al-Raddad (1995), Selvakumar et al. (2016), who reported the inability of Maize plant for AMF multiplication. Meanwhile, Lemon grass also showed tremendous increase in mycorrhizal inoculum after Maize which supports the results of Kaushish et al. (2011).

On comparing the inoculum production efficiency of all the hosts, Palmarosa showed a bit lesser tendency when utilized for the propagation of $A$. laevis which corroborates with our earlier results with sugarcane bagasse (Tanwar et al., 2013). This probably could be due to the short duration of the experiment which might be responsible for the low level of colonization observed in the Palmarosa plant. One more reason could be the poor production and limited secretion of photoassimilates to the AMF symbiont. Even though, efficient inoculum quantity was achieved by Palmarosa is sufficient to be used for multiplication purposes. Sesbania is a member of Leguminosae which are also believed to be a perfect host for AMF multiplication 
(Gill and Singh, 2001). According to Kaushik et al. (2011), they also tried Sesbania for the multiplication of AMF and recorded maximum spore count with vermicompost substrate. In the present investigation, also Sesbania harbored excess spores efficiently colonizing its roots to be utilized for AM multiplication purposes. The interaction between the host plant, AMF species, and type of growth substrate can be stimulatory or inhibitory to the AMF and host and amongst all, type and the concentration of substrate used is foremost for AMF multiplication. As per Moreira et al. (2019), regardless of the inoculum source, the percentage of viable spores exists greater at the layer of 0.00-0.05 m (76.32 \%) compared to the layer of 0.05-0.10 m (72.05\%). Soil amendment up to this range of depth could be productive. This is more likely related to increased available nutrients, porosity and better water holding capacity of the added substrate. For AMF proliferation, a well-aerated substrate deficient in nutrient is considered to be good (Gaur and Adholeya, 2000). The addition of organic residues as a substrate along with soil is known to promote AMF sporulation hence leading to increased inoculum production (Rodrigues and Rodrigues, 2017). Likewise, the addition of SS helped to maintain appropriate soil moisture content, aeration, and space which in turn provide feasible environment for the germination and sporulation of AMF. A perusal of the data showed that the soil amendment with SS had a significant influence on root colonization by AMF, its sporulation and their combined effect on plant development. The addition of SS changes the soil chemical and physical properties which became more conducive for the sporulation of AMF. The soil $\mathrm{pH}$ at the time of this experiment was 6.8 . Angle and Heckman (1986) stated that the addition of SS at a soil pH of 6.2 exhibited a higher degree of mycorrhizal colonization of soybean roots as compared to the addition of the same sludge at a lower $\mathrm{pH}$ 5.7. However, high input of SS proved detrimental for AMF survival which strongly supports the findings of del Val et al. (1999) that this concentration interferes with the growth and proliferation of mycelium and limits the formation of arbuscules.

It is envisaged from the results that the mycorrhizal spore number increased more for G. mosseae as compared to that of $A$. laevis. This corresponds to a change in the soil pH to slightly acidic by the added sludge (Ansari and Jaikishun, 2011), making conditions more conducive for Glomus sp. However, reduction of pH below 5.0 has been reported to be inhibitory to the Glomus survival (Carrenho et al., 2001). Apart from increasing inoculum production of AMF, the effect of the substrate on plant growth is another important issue. After the formation of perfect symbiosis through root colonization and the formation of arbuscules and vesicles, AMF started benefiting the host plant through increased nutrient supply, especially $\mathrm{P}$, as observed in this study. It is believed that the addition of SS increased organic matter and nutrient fertility of the soil especially $\mathrm{N}, \mathrm{P}, \mathrm{K}, \mathrm{Ca}, \mathrm{Mg}, \mathrm{B}, \mathrm{Mn}, \mathrm{Cu}, \mathrm{Mo}$ and $\mathrm{Zn}$, depending upon the specific nature of the sludge material (Dolgen et al., 2004; Haghighi, 2011).

In the present investigation, overall growth inhibition was observed at higher SS concentrations including plant height, plant dry matter except for Lemon grass and Sesbania with both the AMF. Excessive addition of SS is associated with root growth inhibition which is perhaps the most important indicator of SS toxicity (Oleszczuk et al., 2012). Micronutrients such as $\mathrm{Zn}, \mathrm{Cu}$ and Mn can be toxic to AMF at higher concentrations. However, low concentration of these nutrients can increase the percentage of root colonization, extrametrical chlamydospore number, and the number of infective propagules (Sreenivasa and Bagyaraj, 1988). Besides this, increased plant growth on the addition of SS has also been documented by numerous researchers including Wei and Liu (2005), Aslantas et al. (2010). Moreover, Amir et al. (2019) documented seven times higher increased in the dry weight of Metrosideros laurifolia seedlings than the control plants while using AMF and SS together, which are characterized by improved mineral nutrition, a higher $\mathrm{Ca} / \mathrm{Mg}$ ratio, and reduced translocation of heavy metal as well and thereby improved ecological re-establishment of the studied area( ultramafic mine-degraded area). Consequently, soil supplementation with municipal SS can be employed as a source of fertilization for growing sweet basil, a high value crop, by directly affecting its plant growth and physiology (Burducea et al., 2019). Singh and Agrawal (2010) also recommended SS amendment in the soil at $6 \mathrm{~kg} \mathrm{~m}^{-2}$ and below for promoting mung bean yield and nutritional quality. Contrarily higher SS application leads to heavy metal accumulation of $\mathrm{Cd}, \mathrm{Pb}$ and $\mathrm{Ni}$ in the seeds, which is a major cause of concern to human wellness. In this investigation also excessive addition of sludge showed an inhibitory effect and hence should be avoided. Our results are in accordance with those found by Sullivan et al. (2006), Tariq et al. (2012).

\section{Conclusion}

AMF inoculum production method employing trap host roots under pot conditions with carrier substrate is extensively used, since it is less artificial, highly economical and competent in producing highly-efficient inoculants of colonized plant roots on large (Schlemper and Stürmer, 2014). Excessive application of SS 
presents limitations in the AMF survival, sporulation, and reduced ability to colonize host roots and host growth as well. Nonetheless, SS should be viewed as a resource in lieu of a waste product considering its valuable properties and a broad spectrum of potential uses (Kicińska et al., 2019). All the studied plants behaved as highly mycorrhizal plants when propagated in association with appropriate doses of SS. One can utilize these plants for AMF (G. mosseae and A. laevis) multiplication. It is foremost to have an inoculum with the potential to colonize host roots, proliferate in the substrate and also supplement plant growth. Consequently, this inoculum also should be previously tested with host crops either in pots or under field conditions. Apart from this, one more uphill battle for mycorrhizologist is to grow awareness among consumers about the potential benefits of AMF technology for sustainable plant production.

\section{Acknowledgment}

We acknowledge Kurukshetra University, Kurukshetra, for provided a University Research Scholarship to Anju Tanwar to complete this work.

\section{References}

Al-Raddad, A.M., 1995. Mass production of Glomus mosseae spores. Mycorrhiza 5: 229-231.

Amir, H., Cavaloc, Y., Laurent, A., Pagand, P., Gunkel, P., Lemestre, M., Médevielle, V., Pain, A., McCoy, S., 2019. Arbuscular mycorrhizal fungi and sewage sludge enhance growth and adaptation of Metrosideros laurifolia on ultramafic soil in New Caledonia: A field experiment. Science of the Total Environment 651(1): 334-343.

Angle, J.S., Heckman, J.R., 1986. Effect of soil pH and sewage sludge on VA mycorrhizal infection of soybeans. Plant and Soil 93: 437-441.

Ansari, A.A., Jaikishun, S., 2011. Vermicomposting of sugarcane bagasse and rice straw and its impact on the cultivation of Phaseolus vulgaris L. in Guyana, South America. Journal of Agricultural Technology 7(2): 225-234.

Aslantas, R., Angin, I., Karakurt, H., Kose, M., 2010. Vegetative and pomological changes of sour cherry as affected by sewage sludge application. Bulgarian Journal of Agricultural Science 16(6): 740-747.

Bettiol, W., Ghini, R., 2011. Impacts of sewage sludge in tropical soil: A case study in Brazil. Applied and Environmental Soil Science Article ID 212807.

Bhowmik, S.N., Yadav, G.S., Datta, M., 2015. Rapid mass multiplication of Glomus mosseae inoculum as influenced by some biotic and abiotic factors. Bangladesh Journal of Botany 44: 209-214.

Burducea, M., Lobiuc, A., Asandulesa, M., Zaltariov, M.F., Burducea, I., Popescu, S.M., Zheljazkov, V.D., 2019. Effects of sewage sludge amendments on the growth and physiology of sweet basil. Agronomy 9(9): 548.

Carrenho, R., Trufem, S.F.B., Bononi, V.L.R., 2001. Arbuscular mycorrhizal fungi in rhizospheres of three phytobionts established in a revegetated riparian area. Acta Botanica Brasilica 15(1): 115-124.

del Val, C., Barea, J.M., Azcón-Aguilar, C., 1999. Assessing the tolerance to heavy metals of arbuscular mycorrhizal fungi isolated from sewage sludge-contaminated soils. Applied Soil Ecology 11(2-3): 261-269.

Dolgen, D., Alpaslan, M.N., Delen, N., 2004. Use of an agro-industry treatment plant sludge on iceberg lettuce growth. Ecological Engineering 23: 117-125.

Douds, D.D., Schenck, N.C., 1990. Relationship of colonization and sporulation by VA mycorrhizal fungi to plant nutrient and carbohydrate contents. New Phytology 116: 621-627.

Eid, E.M., Hussain, A.A., Taher, M.A., Galal, T.M., Shaltout, K.H., Sewelam, N., 2020. Sewage sludge application enhances the growth of Corchorus olitorius Plants and provides a sustainable practice for nutrient recirculation in agricultural soils. Journal of Soil Science and Plant Nutrition 20: 149-159.

Feldmann, F., Grotkass, C., 2002. Directed inoculum production-shall we be able to design populations of arbuscular mycorrhizal fungi to achieve predictable symbiotic effectiveness? In: Mycorrhizal Technology in Agriculture. Gianinazzi, S., Schüepp, H., Barea, J.M., Haselwandter, K. (Eds.). Birkhäuser, Basel. pp. 261-279.

Feldmann, F., Hallmann, J., Wagner, S., Long, X.Q., Yang, R., Schneider, C., Hutter, I., Ceipek, B., Fan, J., Zheng, X., Wang, C., Feng, G., 2008. Mycorrhizal fungi as biological components of the integrated cucumber production (BIOMYC)promising results for mycorrhizal technology transfer to horticultural practice. In: Mycorrhiza Works. Feldmann, F., Kapulnik, Y., Baar, J. (Eds.). Deutsche Phytomedizinische Gesellschaft, Braunschweig, Germany. pp. 25-38.

Gaur, A., Adholeya, A., 2000. Effects of particle size of soil-less substrates upon AM fungal inoculum production. Mycorrhiza 10: 43-48.

Gerdemann, J.W., Nicolson, Y.H., 1963. Spores of mycorrhizal Endogone species extracted from soil by wet sieving and decanting. Transactions of the British Mycological Society 46: 235-244.

Gianinnazi, S., Vosatka, M., 2004. Inoculum of arbuscular mycorrhizal fungi for production systems: science meets business. Canadian Journal of Botany 982: 1264-1271.

Gill, T.S., Singh, R.S., 2001. Effect of host and substrates on development of VA mycorrhizal colonization and sporulation of Glomus fasciculatum. Indian Phytopathology 5(2): 261-263.

Gómez-Bellot, M.J., Lorente, B., Sánchez-Blanco, M.J., Ortuño, M.F., Nortes, P.A., Alarcón, J.J., 2020. Influence of mixed substrate and arbuscular mycorrhizal fungi on photosynthetic efficiency, nutrient and water status and yield in tomato plants irrigated with saline reclaimed waters. Water 12(2): 438. 
Gupta, M.M., 2017. Differential response of arbuscular mycorrhizal sporocarps in long-term trap culturing. Phytomorphology 67(1\&2): 27-34.

Haghighi, M., 2011. Sewage sludge application in soil improved leafy vegetable growth. Journal of Biological and Environmental Sciences 5(15): 165-167.

Hoagland, D.R., Arnon, D.I., 1950. The water-culture method for growing plants without soil. University of California, College of Agriculture, Agricultural Experiment Station, Berkeley, California, USA. Circular No. 347, 32p. Available at [Access date : 01.04.2021]: http://hdl.handle.net/2027/uc2.ark:/13960/t51g1sb8j

Kapoor, R., Sharma, D., Bhatnagar, A.K., 2008. Arbuscular mycorrhizae in micropropagation systems and their potential applications. Scientia Horticulturae 116: 227-239.

Kaushish, S., Kumar, A., Mangla, C., Aggarwal, A., 2011. Mass multiplication of AM inoculum: effect of hosts and substrates in rapid culturing of Acaulospora laevis. Indian Phytopathology 64(2): 159-163.

Kicińska, A., Gucwa, J., Kosa-Burda, B., 2019. Evaluating Potential for using municipal sewage sludge in the rehabilitation of ground degraded by the sodium processing industry. Bulletin of Environmental Contamination and Toxicology 102: 399-406.

Koide, R.T., Schreiner, R.P., 1992. Regulation of the vesicular-arbuscular mycorrhizal symbiosis. Annual Review of Plant Physiology and Plant Molecular Biology 43: 557-581.

Kokkoris, V., Hart, M., 2019.. In vitro propagation of arbuscular mycorrhizal fungi may drive fungal evolution. Frontiers in Microbiology 10: 2420.

Liu, R., Wang, F., 2003. Selection of appropriate host plants used in trap culture of arbuscular mycorrhizal fungi. Mycorrhiza 13: 123-127.

Lobo, T.F., Filho, H.G., 2009. Sewage sludge levels on the development and nutrition of sunflower plants. Soil Science and Plant Nutrition 9(3): 245-255.

Maiti, D., 2011. Improving activity of native arbuscular mycorrhizal fungi (AMF) for mycorrhizal benefits in agriculture: Status and prospect. Journal of Biofertilizers and Biopesticides S1: 001.

Menge, J.A., Timmer, L.W., 1982. Procedure for inoculation of plants with VAM in the laboratory, greenhouse and field. In: Methods and Principles of Mycorrhizal Research, Schenck, N.C. (Ed.). American Phytopathology Society, St. Paul, MN. pp. 59-68.

Mhlongo, M.I., Piater, L.A., Madala, N.E., Labuschagne, N., Dubery, I.A., 2018. The chemistry of plant-microbe interactions in the rhizosphere and the potential for metabolomics to reveal signaling related to defense priming and induced systemic resistance. Frontiers in Plant Science 9: 112.

Moreira, B.C., Junior, P.P., Jordão, T.C., Silva, M.C.S., Ribeiro, A.P.F., Stürmer, S.L., Salomão, L.C.C., Otoni, W.C., Kasuya, M.C.M., 2019. Effect of inoculation of pineapple plantlets with arbuscular mycorrhizal fungi obtained from different inoculum sources multiplied by the on-farm method. Revista Brasileira de Ciência do Solo 43:e0180148.

Mukerji, K.G., Manoharachary, C., Chamola, B.P., 2002. Techniques in Mycorrhizal Studies, $2^{\text {nd }}$ Edition, Kluwer Academic Publishers, The Netherlands. 553p.

Mukhongo, R.W., Tumuhairwe, J.B., Ebanyat, P., AbdelGadir, A.H., Thuita, M., Masso, C., 2016. Production and use of arbuscular mycorrhizal fungi inoculum in Sub-Saharan Africa: challenges and ways of improving. International Journal of Soil Science 11: 108-122.

Nzanza, B., Marais, D., Soundy, P., 2011. Response of tomato (Solanum lycopersicum L.) to nursery inoculation with Trichoderma harzianum and arbuscular mycorrhizal fungi under field conditions. Acta Agriculturae Scandinavica B-Soil and Plant Science 63(3): 209-215.

Oladejo, J., Shi, K., Luo, X., Yang, G., Wu, T., 2019. A Review of Sludge-to-Energy Recovery Methods. Energies 12(1): 60.

Oleszczuk, P., Malara, A., Jośko, I., Lesiuk, A., 2012. The phytotoxicity changes of sewage sludge-amended soils. Water, Air, and Soil Pollution 223: 4937-4948.

Phillips, J.M., Hayman, D.S., 1970. Improved procedures for clearing roots and staining parasitic and vesiculararbuscular mycorrhizal fungi for rapid assessment of infection. Transactions of the British Mycological Society 55: 158-161.

Pöykiö, R., Watkins, G., Dahl, O., 2019. Characterisation of municipal sewage sludge as a soil improver and a fertilizer product. Ecological Chemistry and Engineering S 26(3): 547-557.

Rodrigues, K.M., Rodrigues, B.F., 2017. Development of carrier based in vitro produced arbuscular mycorrhizal (AM) fungal inocula for organic agriculture. Annals of Advanced Agricultural Sciences 1(1): 26-37.

Rosiek, K., 2020. Directions and challenges in the management of municipal sewage sludge in Poland in the context of the circular economy. Sustainability 12(9): 3686.

Ryan, M.H., Graham, J.H., 2002. Is there a role for arbuscular mycorrhizal fungi in production agriculture? Plant and Soil 244: 263-271.

Schenck, N.C., Perez, Y., 1990. Manual for the identification of VA mycorrhizal (VAM) fungi. $3^{\text {rd }}$ Edition, Synergistic Publications, Florida, USA. 286p.

Schlemper, R.T., Stürmer, S.L., 2014. On farm production of arbuscular mycorrhizal fungi inoculum using lignocellulosic agrowastes. Mycorrhiza 24(8): 571-580.

Selvakumar, G., Kim, K., Walitang, D., Chanratana, M., Kang, Y., Chung, B., Sa, T., 2016. Trap culture technique for propagation of arbuscular mycorrhizal fungi using different host plants. Korean Journal of Soil Science and Fertilizer 49(5): 608-613. 
Selvakumar, G., Shagol, C.C., Kim, K., Han, S., Sa, T., 2018. Spore associated bacteria regulates maize root K+/Na+ ion homeostasis to promote salinity tolerance during arbuscular mycorrhizal symbiosis. BMC Plant Biology 18(1): 109.

Simpson, D., Daft, M.J., 1990. Interactions between water-stress and different mycorrhizal inocula on plant growth and mycorrhizal development in maize and sorghum. Plant and Soil 121: 179-186.

Singh, R.P., Agrawal, M., 2010. Effect of different sewage sludge applications on growth and yield of Vigna radiata L. field crop: Metal uptake by plant. Ecological Engineering 36(7): 969-972.

Smith, S.E., Read, D.J., 2008. Mycorrhizal Symbiosis, $3^{\text {rd }}$ Edition, Academic Press, London, UK. 803p.

Sreenivasa, M.N., Bagyaraj, D.J., 1988. Selection of a suitable substrate for mass multiplication of Glomus fasciculatum. Plant and Soil 109: 125-127.

Sullivan, T.S., Stromberger, M.E., Paschke, M.W., 2006. Parallel shifts in plant and soil microbial communities in response to biosolids in a semi-arid grassland. Soil Biology and Biochemistry 38: 449-459.

Tahat, M.M., Sijam, K., 2012. Mycorrhizal fungi and abiotic environmental conditions relationship. Research Journal of Environmental Sciences 6(4): 125-133.

Tanwar, A., Aggarwal, A., Yadav, A., Parkash, V., 2013. Screening and selection of efficient host and sugarcane bagasse as substrate for mass multiplication of Funneliformis mosseae. Biological Agriculture and Horticulture 29(2): 107117.

Tariq, U., Rehman, S., Khan, M.A., Younis, A., 2012. Agricultural and municipal waste as potting media components for the growth and fl owering of Dahlia hortensis 'Figaro'. Turkish Journal of Botany 36: 378-385.

Uko, A.E., Effa, E.B., Isong, I.A., Effiong, J.E., 2020. Yield performance and leaf nutrient composition of bambara groundnut under arbuscular mycorrhizal inoculation in a poultry manure amended ultisol. Pakistan Journal of Biological Sciences 23: 1397-1407.

Wei, Y., Liu, Y., 2005. Effects of sewage sludge compost application on crops and cropland in a 3-year field study. Chemosphere 59(9): 1257-1265.

Whiteside, M.D., Werner, G.D.A., Caldas, V.E.A., van't Padje, A., Dupin, S.E., Elbers, B., Bakker, M., Wyatt, G.A.K., Klein, M., Hink, M.A., Postma, M., Vaitla, B., Noë, R., Shimizu, T.S., West, S.A., Kiers, E.T., 2019. Mycorrhizal fungi respond to resource inequality by moving phosphorus from rich to poor patches across networks. Current Biology 29(12): 2043-2050. 